\title{
Grazing Pressure of Cattle on Mixed Pastures at Coal Mine Land Reclamation
}

\author{
T. P. Daru ${ }^{a}{ }^{*}$, S. Hardjosoewignjo ${ }^{b}$, L. Abdullah ${ }^{b}$, Y. Setiadi $^{c}$, \& Riyanto ${ }^{a}$ \\ ${ }^{a}$ Faculty of Agriculture Mulawarman University \\ Kampus Gunung Kelua, Jl. Pasir Balengkong, Samarinda, Indonesia \\ ${ }^{b}$ Faculty of Animal Science, Bogor Agricultural University \\ Jln. Agatis, Kampus IPB Darmaga Bogor 16680, Indonesia \\ ${ }^{\mathrm{C}}$ Faculty of Forestry, Bogor Agricultural University \\ Jln. Lingkar Akademik, Kampus IPB Darmaga Bogor 16680, Indonesia \\ (Received 10-01-2011; accepted 27-02-2012)
}

\begin{abstract}
ABSTRAK
Tujuan penelitian ini adalah untuk menentukan tekanan penggembalaan di padang rumput campuran signal (Brachiaria decumbens) dan puero (Pueraria phaseoloides) di lahan reklamasi tambang batubara. Percobaan disusun dalam rancangan acak kelompok yang terdiri atas 5 perlakuan tekanan penggembalaan, yaitu masing-masing 12,$56 ; 19,63 ; 28,26 ; 38,47$; dan $50,24 \mathrm{~m}^{2}$.ekor ${ }^{-1}$.hari ${ }^{-1}$ yang dilakukan dengan cara mengikat sapi untuk merumput dengan panjang tali tambatan berturut turut 2,0;2,5;3,0; 3,5; dan 4,0 m. Sistem rotasi digunakan dengan memodifikasi tali tambatan. Setiap periode rotasi adalah 30 hari selama tiga periode rotasi. Hasil penelitian menunjukkan bahwa pertambahan bobot badan harian $(\mathrm{PBBH})$ berbeda nyata $(\mathrm{P}<0,05)$ akibat tekanan penggembalaan yang berbeda. Total pertambahan tertinggi diperoleh pada panjang tali 2,0 m atau luas penggembalaan 12,56 m².ekor-1.hari-1 dan menurun secara linier dengan meningkatnya panjang tali dari 254,29 sampai 100,17 kg.ha ${ }^{-1}$. Konsumsi bahan kering maksimum dicapai pada panjang tali 3,32 m atau luas penggembalaan $34,61 \mathrm{~m}^{2}$.ekor-1.hari ${ }^{-1}$. Ratarata hasil bahan kering adalah $235,39 \mathrm{~g} \cdot \mathrm{m}^{-2} \cdot$ hari $^{-1}$ atau 2,35 ton.ha- ${ }^{-1} \cdot$ bulan $^{-1}$. Komposisi botani rumput signal, puero, dan gulma berubah sebelum dan sesudah penggembalaan.
\end{abstract}

Kata kunci: lahan reklamasi, tambang batubara, stocking rate, komposisi botani

\section{ABSTRACT}

The objective of the research was to determine the grazing pressure in mix pasture of signal grass (Brachiaria decumbens) and puero (Pueraria phaseoloides) at coal mining reclamation. The experiment was arranged by randomized block design consisted of 5 stocking rate treatments, those were 12.56, 19.63, 28.26, 38.47, and $50.24 \mathrm{~m}^{2}$.animal ${ }^{-1} . \mathrm{d}^{-1}$ which were equal to length of tether rope of 2.0, 2.5, 3.0, 3.5, and $4.0 \mathrm{~m}$, respectively. The rotation system was applied by modifying the tether. Each rotation period was $30 \mathrm{~d}$ of three-rotation period. Result of this experiment showed that average daily gain (ADG) was different $(\mathrm{P}<0.05)$ with different grazing pressure. Highest total gain has achieved at length of tether rope $2.0 \mathrm{~m}$ or grazing area $12.56 \mathrm{~m}^{2}$.animal-1. $\mathrm{d}^{-1}$ and decreased linearly with increasing length of rope from 254.29 to $100.17 \mathrm{~kg} \cdot \mathrm{ha}^{-1}$. Maximum dry matter consumption was achieved at length of tether rope of $3.32 \mathrm{~m}$ or grazing area $34.61 \mathrm{~m}^{2}$.animal ${ }^{-1} \cdot \mathrm{d}^{-1}$. Average dry matter yield in this experiment was 235.39 g.m $\mathrm{m}^{-2} \cdot \mathrm{d}^{-1}$ or 2.35 ton.ha ${ }^{-1} \cdot \mathrm{mo}^{-1}$. Botanical composition of signal grass, puero, and weeds before and after grazing was change with grazing pressure.

Key words: land reclamation, coal mine, stocking rate, botanical composition

\section{INTRODUCTION}

The cultivation of grass and legume in land reclamation is important. Grass is often used as a cover crop because it is generally easier to adapt to the already

* Corresponding author:

E-mail: taufan.pd@gmail.com disturbed areas, tolerant of environmental variation and guarantee of availability of seeds. While legume besides being able to maintain soil stability, may also be capable of being symbiosis with rizobia that fix nitrogen from the air and then transferred into the soil. Both of these plants can also build soil organic matter, thus is created the soil ecosystem-plants-animals (Shrestha \& Lal, 2007; Zackrisson, 2004). 
Soils which are covered by vegetation of grass and legume allow livestock to graze. However, livestock grazing on post-mining land reclamation is not as easy on natural pasture or pastures that are intended for grazing. Wasteland (Mine Spoil) in mine land reclamation program has a structure that has not stabilized and land ecosystems that have not fully recovered. Therefore to develop the livestock on post-mining land requires careful management to avoid soil compaction and erosion (Akala \& Lal, 2001).

Grazing pressure (number of animals per area of land or land area per number of animals) is an important factor in terms of grazing management. This will determine the persistence pastures, animal productivity and performance. If grazing pressure is too high, the output per head of cattle will be low, and erosion and weed will be happened. Conversely, if grazing pressure is too low, the animal production per head will be high and the production of cattle per hectare is low, botanical composition will change, so that the paddock will be dominated by plants that are less preferred by animals. In the long term this conditions will reduce livestock production and lowering the carrying capacity of pastures. Therefore, it should be managed in order to obtain an optimum grazing pressure where livestock production per head and per hectare achieve on maximum production and carrying capacity of pastures will sustain (Manske, 2004; Mourinõ et al., 2003).

The purpose of this study was to determine the magnitude of grazing pressure by the young Brahman male in mix pastures of signal grass (Brachiaria decumbens) and puero (Pueraria phaseoloides) on land reclaimed.

\section{MATERIALS AND METHODS}

\section{Location and Time}

The experiment was conducted on the land after the coal mining at Sangatta South East (SSE), PT Kaltim Prima Coal (KPC), Sengata, East Kalimantan, for $90 \mathrm{~d}$. Land used in this experiment was post-mining land reclaimed in 2001, containing various kinds of shrubs, small trees mixed with signal grass and puero and other ground cover plants.

The soil of the land has a $\mathrm{pH}\left(\mathrm{H}_{2} \mathrm{O}\right) 5.10,1.17 \%$ C-organic content, $0.09 \%$ N-total, 8.88 ppm.P Bray I, $28.60 \% \mathrm{P} \mathrm{HCl}, 0.89 \mathrm{me} / 100 \mathrm{~g} \mathrm{Ca}, 4.71 \mathrm{me} / 100 \mathrm{~g} \mathrm{Mg}, 0.20$ me/100 g K, 0.17me/100 g Na, 7.73 me/100 g CEC, 77.20\% base saturation, $1.16 \mathrm{me} / 100 \mathrm{~g} \mathrm{Al}, 0.24 \mathrm{me} / 100 \mathrm{~g} \mathrm{H}, 19.84$ $\mathrm{me} / 100 \mathrm{~g} \mathrm{Fe}, 20.00 \mathrm{me} / 100 \mathrm{~g} \mathrm{Cu}, 21.80 \mathrm{me} / 100 \mathrm{~g} \mathrm{Zn}$, and $8.72 \mathrm{me} / 100 \mathrm{~g} \mathrm{Mn}$. The texture of the soil composed of $36.18 \%$ sand, $27.22 \%$ dust, and $36.60 \%$ clay.

\section{Land Pasture Preparation}

The land was cleared (land clearing), and fertilized by NPK (16-16-16) of $200 \mathrm{~kg} \cdot \mathrm{ha}^{-1}$ and liquid compost with concentration $50 \mathrm{~L}$ in 10,000 of water. Compost was made by fermenting of $10 \mathrm{~kg}$ of cow dung dissolved in $200 \mathrm{~L}$ water added with $1 \mathrm{~L}$ of bio-activator, consisting of a mixture of enzymes, amino acids, hormones, humic acid as well as some essential micro elements that can activate soil microbes. The content of liquid compost was made up of elements of C $0.18 \%$, N 297.99 ppm, P 100.70 ppm, K 200.70 ppm, Ca 54.20 ppm, Mg 100.50 ppm, Fe 2.11 ppm, Zn 0.53 ppm, Mn 3.75 ppm, B 80.70 ppm, Mo 0.02 ppm Mo, and pH 6.50. The land was then spread with a mixture of $40 \mathrm{~kg}$ of signal grass seed and $40 \mathrm{~kg}$ of puero legumes seed.

The treatments of this experiment were grazing pressure based on large of grazing (Table 1). After 90d-old plants, trimming was done as high as $5 \mathrm{~cm}$ above the soil surface by using a lawn mower. By the time of $30 \mathrm{~d}$ of age plant, prior to the experiment, the botanical composition of pastures by dry weight rank method was calculated. Sampling was done outside the experimental plots of each treatment using iron quadrant size $1 \times 1 \mathrm{~m}$. The forage production was calculated by the assumption of the consumption of dry matter of cattle by $3 \%$ of their body weight, then it can be determined the range of grazing pressure.

The level of forage consumption was measured by cutting the forage in each plot experiments that were not consumed and compared with the forage derived from the area of grazed by cutting up the soil surface area of $1 \mathrm{~m}^{2}$. Each forage sample was dried in oven at $65{ }^{\circ} \mathrm{C}$ for $2 \mathrm{~d}$. The difference between the dry weight of forage derived from areas that were not grazed with the amount of forage were grazed is the forage consumed by animal.

The experiments used 15 male Brahman hybrid cattle aged 18-24 mo with an average body weight $124.31 \pm 11.11 \mathrm{~kg}$. Cattle were placed in communal cages equipped with a water tower.

Rotational grazing was modified by using a rope tied (Figure 1). The length of tether was the implementation of the grazing area per day. Long of grazing

Table 1. Experimental design of grazing pressure based on large of grazing

\begin{tabular}{cccccc}
\hline Treatments & $\begin{array}{c}\text { Large of experi- } \\
\text { ment plots }\left(\mathrm{m}^{2}\right)\end{array}$ & $\begin{array}{c}\text { Length of rope } \\
(\mathrm{m})\end{array}$ & $\begin{array}{c}\text { Area per day } \\
\left(\mathrm{m}^{2}\right)\end{array}$ & $\begin{array}{c}\text { Area per 30 days } \\
\left(\mathrm{m}^{2}\right)\end{array}$ & $\begin{array}{c}\text { Grazing pressure } \\
\left.(\text { AU ha })^{-1}\right)\end{array}$ \\
\hline G1 & 560.00 & 2.00 & 12.56 & 367.80 & 8.43 \\
G2 & 840.00 & 2.50 & 19.63 & 588.90 & 5.26 \\
G3 & $1,120.00$ & 3.00 & 28.26 & 847.80 & 3.66 \\
G4 & $1,400.00$ & 3.50 & 38.47 & $1,154.10$ & 2.69 \\
G5 & $1,680.00$ & 4.00 & 50.24 & $1,507.20$ & 2.06 \\
\hline
\end{tabular}

Note: G1= length of rope $2.0 \mathrm{~m}, \mathrm{G} 2=$ length of rope $2.5 \mathrm{~m}, \mathrm{G} 3=$ length of rope $3.0 \mathrm{~m}, \mathrm{G} 4=$ length of rope $3.5 \mathrm{~m}$, and G5= length of rope $4.0 \mathrm{~m}$. 


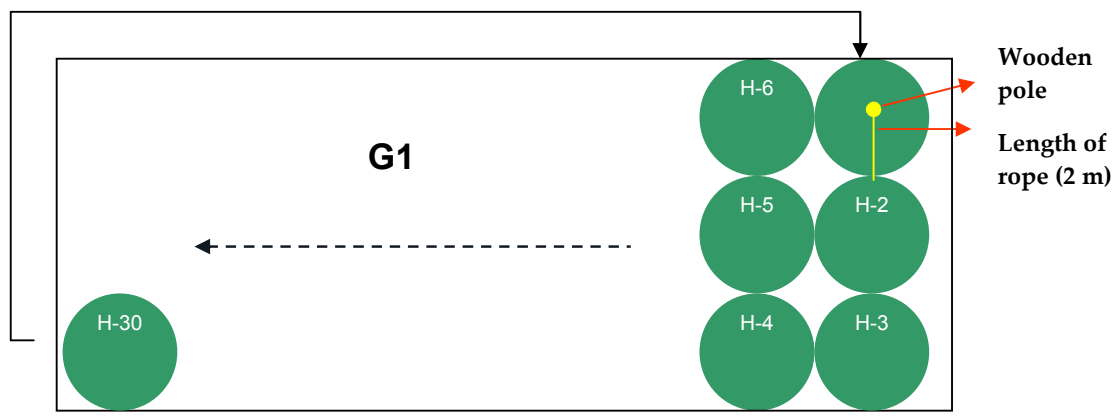

Figure 1. Model of rotation grazing in the treatment sample G1. The first day (H-1) cattle were tied at $1.50 \mathrm{~m}$ wooden pole with a length of rope $2 \mathrm{~m}$. On day two (H-2) cattle moved into other areas in one paddock until day 30 . After 30 days, cattle moved back to the first area and so on until day 90.

experiment in the plot was $30 \mathrm{~d}$ (Mansyur et al., 2006). Data were collected for $90 \mathrm{~d}$ in order to obtain three rotations. During the trial, the monthly rainfall recorded was 202.3, 212.9, and $287.3 \mathrm{~mm}$, respectively, with an average of $234.17 \mathrm{~mm}$.

Cattle were allowed to graze for $7 \mathrm{~h}$ continuously between 9 am until 4 pm, and given to drink ad libitum. Before grazing cattle were given bran as much as $1 \mathrm{~kg}$ per animal per day administered individually and placed in a plastic basin for each animal. After grazing, animals were caged.

\section{Statistical Analysis}

The experiments were arranged in a simple randomized block design consisting of five treatments of grazing pressure (Table 1). Each treatment was replicated 3 times. The data were analyzed by analysis of variance, and the differences between the treatments were analyzed by Duncan's multiple range test. The variables measured were the relative frequency, botanical composition, dry weight forage, forage dry matter intake, daily weight gain (DWG), and total weight gain (DWG ha-1).

\section{RESULTS AND DISCUSSION}

\section{Relative Frequency and Composition Botanist}

The pastures of this experiment had high plant species diversity. This condition is seen in relative fre-

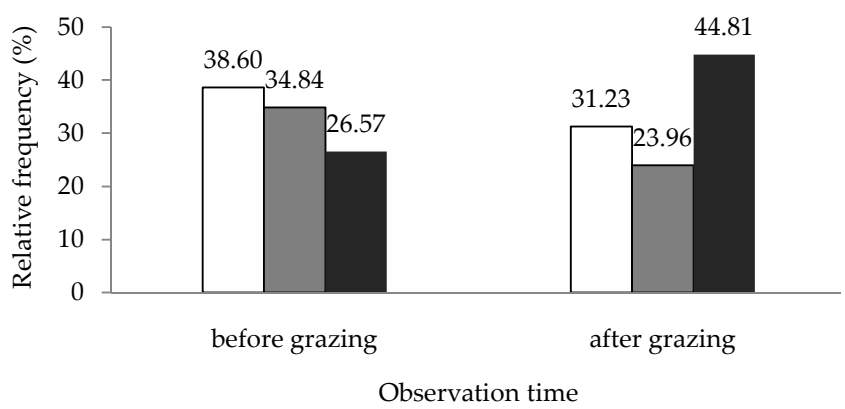

Figure 2. Relative frequency between signal ( $\square)$, puero $(\square)$, and weeds ( - on pastures experimental observations before and after grazing quency between the signals, puero, and weeds before and after grazing, where the relative frequency of signal and puero lower than expected growth. The composition of the signal and puero after grazing also decreased when compared to weeds (Figure 2).

After grazing, the relative frequency of cover crops appears to change. The portion of the signal decreased to $31.23 \%$ and puero $23.96 \%$, and weeds increased to $44.81 \%$. Weeds were identified at pastures contained 16 species (Table 2). Some of which increased after grazing, such as Cyperus aromaticus, Cyperus rotundus, and Melastoma malabathricum. These weed species are generally not preferred by animal.

Increasing the composition of prior grazing with weeds after grazing may be caused by two possibilities. First, during grazing, the animals do not only eat grass but also weeeds that have flowered. Since weed seeds

Tabel 2. The types of weeds present and their relative frequency in the experiment pastures

\begin{tabular}{lcc}
\hline \multirow{2}{*}{ Species } & \multicolumn{2}{c}{ Relative frequency (\%) } \\
\cline { 2 - 3 } & Before grazing & After grazing \\
\hline Acrosticbum aureum & 0.60 & 1.23 \\
Ageratum conyzoides & 1.42 & 0.00 \\
Axonopus compressus & 1.36 & 1.47 \\
Casia seamea & 0.00 & 1.31 \\
Centrosema pubescens & 0.49 & 0.00 \\
Cyperus aromaticus & 2.99 & 4.99 \\
Cyperus rotundus & 5.39 & 10.06 \\
Dicranopteris linearis & & \\
(Gleichemia linearis) & 0.44 & 0.00 \\
Fimbristylis acuminata & 2.56 & 2.13 \\
Imperata cylindrica & 2.23 & 3.92 \\
Melastoma malabathricum & 2.29 & 5.72 \\
Mikania cordata & 2.01 & 3.84 \\
Paspalum dilatatum & 2.99 & 1.14 \\
Pillanthus emblica & 1.03 & 0.98 \\
Scleria sumatrensis & 0.11 & 7.52 \\
Sellagenela sp. & 0.65 & 0.49 \\
\hline
\end{tabular}


are not digested properly, it spreads through the feces. In rainy conditions (an average of $234.17 \mathrm{~mm} / \mathrm{mo}$ ), these seeds grows fast. Second, the competitive effect between not favored plants (unpalatable) with a preferred plant (palatable). This competition does not only occur due to the many plants that are consumed but also the nature of the growth of undesirable plants. Noble (1994) reported that unpalatable plants would grow stronger so that the balance between plants that were not favored with the more preferred plants was greater. Furthermore, Manske (2004) reported that the animal will choose the preferred crop, so plant not preferred increased.

The high indigenous plants which become a weed is a description of the land before. Disturbed land by coal mining was reclaimed in 2001. In the process of reclamation was planted various types of cover crops, such as grasses, legumes, shrubs and trees. Plants are naturally distributed in the reclamation activities to build a community together with indigenous plants. In the development, the indigenous plants dominate the space in a community and save a lot of seed reserves in the soil surface (Sanderson et al., 2007). Despite the clearance of land (land clearing) was done before replanted with the crop trials, they still have a high frequency in space. According to Holl (2002) initial vegetation composition of a process of succession is an important step in postmining land reclamation program. Initial vegetation can act as facilitators or inhibitors in the development of the next succession. In this condition, it appears that the spread of cover crops in this reclamation program, although non-native species, has a role as a facilitator or tolerant in the process of succession so that the species of indigenous (native) had the opportunity to revegetation which in turn will replace the space of species introductions. Therefore, the relative frequency of weeds in field trials was relatively high.

Attention to botanical composition before and after grazing seems to have the same pattern with relative frequency signal, puero and weeds, where the portion of weeds increased after grazing. Botanical composition of signal and puero before grazing was not significantly difference due to different grazing pressure treatment, but it was significantly difference $(\mathrm{P}<0.05)$ in the weeds. The highest weed botanical composition was obtained in the treatment of G4 (3.5 m length of rope or on area $38.47 \mathrm{~m}^{2}$ animal ${ }^{-1} \mathrm{~d}^{-1}$ ), i.e. $21.58 \%$. After grazing, only portion of signal increased significantly $(\mathrm{P}<0.05)$, whereas puero and weeds did not significantly difference. The treatment of G1 (2.0 m length of rope or on area 12.56 $\mathrm{m}^{2}$ animal ${ }^{-1} \mathrm{~d}^{-1}$ ) was not significantly different with $\mathrm{G} 2$, but it significantly different to treatment G3, G4, and G5 (Table 3). The changing of botanical composition on pasture due to grazing pressure could decline of forage differences and livestock production (Franzluebbers et al., 2004).

The higher composition of signal at high of grazing pressure (Table 3) can be caused by stimulation of regrowth. If the remaining parts of the plant stand, it as soon as possible builds new shoots, which form tillers or stems (DeRamus, 1995). This condition provides an opportunity for plants to build new shoots (sprouting) quickly. There are two processes of new shoots. First, increase the activation of bud seedlings (Tiller buds), that highly depends on process of photosynthesis and leaves remaining during grazing. Second, ratio carbohydrate content on the pseudostem and carbohydrate present in the tissue deposits (Sutter et al., 2001). In addition, nutrients play a role in the persistence and crop production (Wadi et al., 2003). Abdullah (2009) showed that application of inorganic fertilizer can increase stolon length and number of signal grass seedlings.

\section{Dry Matter Production, Dry Matter Consumption, and Body Weight Gain}

Dry matter production of forage was not significantly $(\mathrm{P}>0.05)$ influenced by grazing pressure treatment. This condition indicates that the production of dry matter forage was similar in all treatments. Dry matter consumption, daily weight gain (DWG) and total weight gain $(\mathrm{TWG})$ were significantly difference $(\mathrm{P}<0.05)$ among the treatment of grazing pressure.

Dry matter consumption increased in a quadratic pattern $(Y=7369.70+6014.60 x-906.50 \times 2 ; R 2=0.86)$ with increasing length of rope or the area of grazing per day. Based on these equations, the optimum DM consumption was happened at length of rope at $3.32 \mathrm{~m}$ or grazing area of $34.61 \mathrm{~m}^{2}$ animal-1 $\mathrm{d}^{-1}$ (Figure 3). When compared to the research of Hirata et al. (2003) using Paspalum notatum grass, the dry matter intake of forage which was ranged from 19.9 to $59.2 \mathrm{~g} \mathrm{DM} \mathrm{m}^{-2} \mathrm{~d}^{-1}(688.74-2$ 048,91 $\mathrm{g}$ $\mathrm{d}^{-1}$ ) was lower than those of this study.

Tabel 3. The average of botanical composition of signal, puero, and weeds before and after grazing on the different grazing pressures $(\%)$

\begin{tabular}{|c|c|c|c|c|c|c|}
\hline \multirow{2}{*}{ Treatments } & \multicolumn{3}{|c|}{ Before grazing } & \multicolumn{3}{|c|}{ After grazing } \\
\hline & Signal & Puero & Weeds & Signal & Puero & Weeds \\
\hline G1 & $59.18 \pm 2.75$ & $21.09 \pm 5.44$ & $19.72 \pm 7.12^{\mathrm{ab}}$ & $56.05 \pm 2.32^{\mathrm{a}}$ & $22.16 \pm 2.85$ & $21.79 \pm 0.60$ \\
\hline G2 & $62.54 \pm 3.34$ & $28.02 \pm 3.02$ & $9.44 \pm 0.58^{c}$ & $52.20 \pm 6.08^{\mathrm{a}}$ & $23.07 \pm 1.79$ & $24.73 \pm 7.72$ \\
\hline G3 & $55.17 \pm 5.54$ & $31.39 \pm 4.69$ & $13.44 \pm 4.80^{\mathrm{abc}}$ & $42.39 \pm 7.65^{b}$ & $21.85 \pm 7.79$ & $35.76 \pm 5.42$ \\
\hline G4 & $57.33 \pm 5.86$ & $21.09 \pm 7.51$ & $21.58 \pm 1.64^{\mathrm{a}}$ & $38.78 \pm 7.51^{\mathrm{b}}$ & $20.59 \pm 6.34$ & $40.63 \pm 7.96$ \\
\hline G5 & $59.94 \pm 3.30$ & $26.93 \pm 7.50$ & $13.12 \pm 6.49^{\mathrm{bc}}$ & $42.84 \pm 3.90^{\mathrm{b}}$ & $19.51 \pm 3.72$ & $37.65 \pm 1.77$ \\
\hline
\end{tabular}

Note: G1= length of rope $2.0 \mathrm{~m}, \mathrm{G} 2=$ length of rope $2.5 \mathrm{~m}, \mathrm{G} 3=$ length of rope $3.0 \mathrm{~m}, \mathrm{G} 4=$ length of rope $3.5 \mathrm{~m}$, and G5= length of rope $4.0 \mathrm{~m}$. Means in the same column with difeerent superscript differ significantly $(\mathrm{P}<0.05)$. 
When comparing between the consumption of dry matter per animal per day to dry matter production per area per day, there was a decrease in the percentage of dry matter intake with increasing area of the experiment. It means that the wider grazing area, the lower the percentage of available forage dry matter consumed (Figure 4). Selection of plant parts as well as the availability of forage by grazing pressure treatment provides a response to the consumption of dry matter forage. At high grazing pressure dry matter consumption is low (1140.10 $\mathrm{g}$ animal $^{-1} \mathrm{~d}^{-1}$ ), because its availability was low. The optimum grazing pressure was at $3.32 \mathrm{~m}$ length of rope or on the total grazing area of $34.61 \mathrm{~m}^{2}$ animal $^{-1}$ $\mathrm{d}^{-1}$. The low consumption of dry matter forage on treatments G4 and G5 when compared to G3, was caused by portions of the plant consumed. It has been explained that the larger grazing area will provide an opportunity for animal to choose the preferred plant parts, especially the young shoot. The consumption of dry matter in the treatment of G4 and G5 was low due to animals of these treatments ate young shoots that have a lower dry matter content (Nelson \& Moser, 1994).

The daily weight gain (DWG) significantly increased $(\mathrm{P}<0.05)$ with the low grazing pressure or the extent of the area per animal grazing (Table 4). Consumption of dry matter seems closely related to daily weight gain of animal experiments. The results indicate that a significantly difference in terms of daily weight gain was due to grazing pressure treatments. Daily weight gain in the treatment of G1 (length of rope

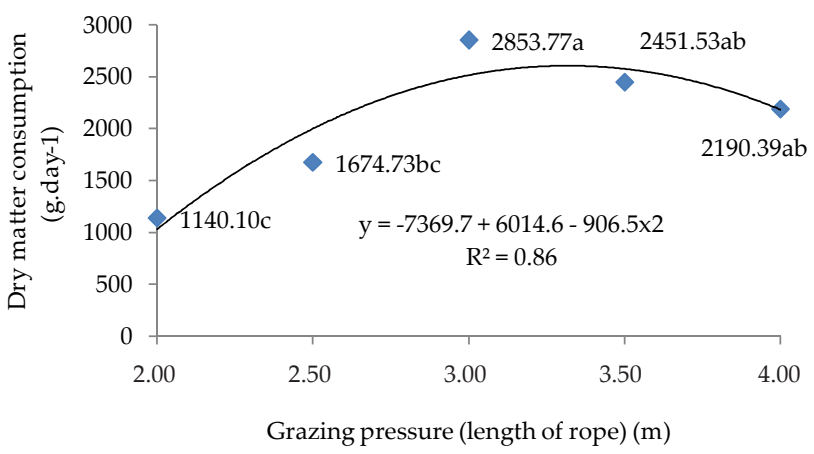

Figure 3. Dry matter consumption in the different grazing pressures

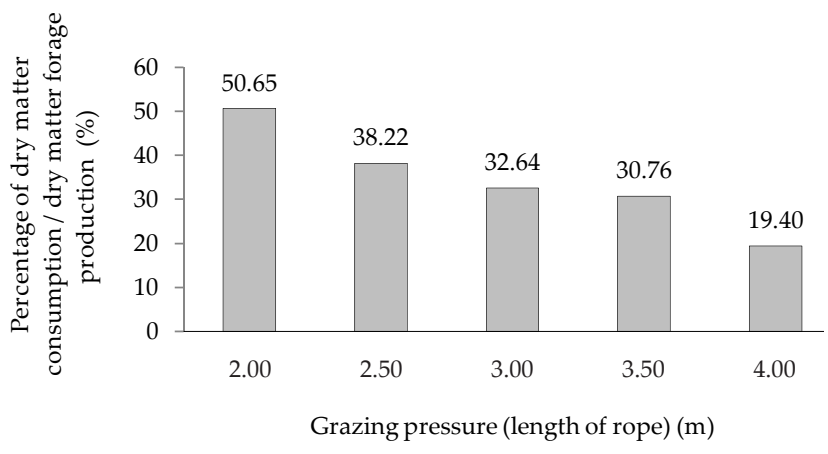

Figure 4. Percentage of forage dry matter consumption to dry matter forage production based on different grazing pressure
Table 4. Average forage dry matter production and daily weight gain in the different grazing pressures

\begin{tabular}{ccc}
\hline Treatments & $\begin{array}{c}\text { Forage dry matter } \\
\text { production }\left(\mathrm{g} . \mathrm{m}^{-2}\right)\end{array}$ & $\begin{array}{c}\text { Daily weight gain } \\
\left(\mathrm{g} . \mathrm{d}^{-1}\right)\end{array}$ \\
\hline G1 & $193.32 \pm 62.24$ & $335.16 \pm 60.44^{\mathrm{b}}$ \\
G2 & $232.66 \pm 46.86$ & $439.56 \pm 148.66^{\mathrm{ab}}$ \\
G3 & $310.53 \pm 80.96$ & $556.78 \pm 192.96^{\mathrm{a}}$ \\
G4 & $210.49 \pm 54.71$ & $553.11 \pm 201.69^{\mathrm{a}}$ \\
G5 & $229.97 \pm 28.79$ & $540.29 \pm 149.50^{\mathrm{a}}$ \\
\hline
\end{tabular}

Note: G1= length of rope $2.0 \mathrm{~m}, \mathrm{G} 2=$ length of rope $2.5 \mathrm{~m}$, G3= length of rope $3.0 \mathrm{~m}$, G4= length of rope $3.5 \mathrm{~m}$, and G5= length of rope 4.0 $\mathrm{m}$. Means in the same column with difeerent superscript differ significantly $(\mathrm{P}<0.05)$.

$2.0 \mathrm{~m}$ or grazing area $12.56 \mathrm{~m}^{2}$ animal-1 $\mathrm{d}^{-1}$ ) was 335.16 g.d $\mathrm{d}^{-1}$. The low weight gain of G1 was due to treatment of low forage availability.

Total weight gain per hectare (TWG) decreased linearly with reduced grazing pressure or increased with increasing grazing pressure $\left(\mathrm{Y}=405\right.$ to $76.48 \mathrm{x} ; \mathrm{R}^{2}$ $=0.99$ ) (Figure 5). The same pattern also occurred in the study of Phillips \& Coleman (1995) and Ackerman et al. (2001). This condition indicates that the maximum grazing pressure, i.e. at $2.0 \mathrm{~m}$ length of rope (8.43 AU $\mathrm{ha}^{-1}$ ) with the total weight gain $254.29 \mathrm{~kg} \mathrm{ha}^{-1}$. In these experiments were still in the low range and possible to increase the grazing pressure. According to Studemann \& Franzluebbers (2007), low forage biomass could only support the number of livestock and low weight gain. These results differ from studies Gunter et al. (2005) who reported that the resulting pattern was quadratic with optimal grazing pressure on $8.9 \mathrm{AU} \mathrm{ha}^{-1}$ or Ako (2007) which optimal grazing pressure of 12 animals per hectare using elephant grass.

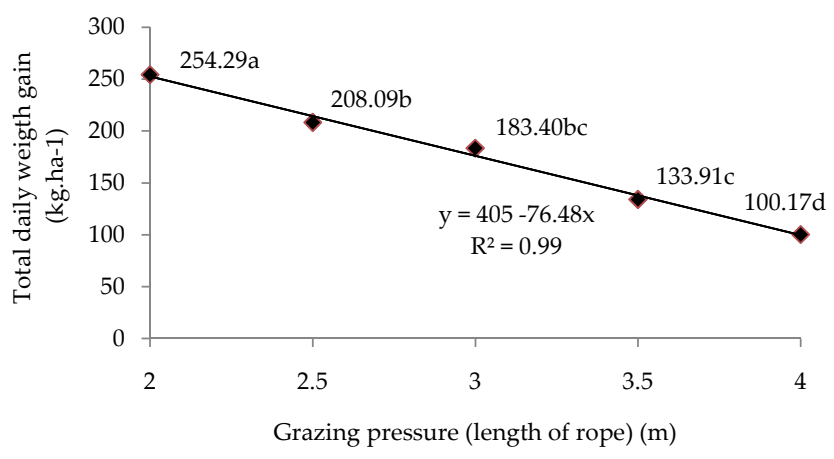

Figure 5. Total daily weight gain per hectare on different grazing pressure

\section{CONCLUSION}

The maximum grazing pressure was $8.43 \mathrm{AU} \mathrm{ha}^{-1}$, and produce highest total weight gain $\left(\mathrm{kg} \mathrm{ha}^{-1}\right)$. The botanical composition changed before and after grazing. 


\section{ACKNOWLEDGEMENT}

We would like to express gratitude to General Manager of Health, Safety and Environment and Manager of Environment Department PT Kaltim Prima Coal (KPC) which has facilitated this study.

\section{REFERENCES}

Abdullah, L. 2009. Pola pertumbuhan rumput signal (Brachiaria humidicola (Rendle) Schweick) pada padang penggembalaan dengan aplikasi sumber nutrien berbeda. Med. Pet. 32: $71-80$.

Ackerman, C. J., H. T. Purvis, G. W. Horn, S. I. Paisley, R. R. Reuter, \& T. N. Bodine. 2001. Performance of light vs heavy steers grazing plains old world bluestream at three stocking rates. J. Anim. Sci. 79: 493-499.

Akala, V. A. \& R. Lal. 2001. Soil organic carbon pools and sequestration rates in reclaimed minesoils in Ohio. J. Environ. Qual. 30 : 2098-2104.

Ako, A. 2007. Grazing adaptability of beef cattle on the dwarf napiergrass (Pennisetum purpureum Schumach) pasture. Med. Pet. 30: 48-54.

DeRamus, H. A. 1995. Forage Growth and its Relatisonship to Grazing Management. http://www.lousiana.edu/ [19 Agustus 2009].

Franzluebbers, A. J., S. R. Wilkinson, \& J. A. Stuedemann. 2004. Bermudagrass management in the Southern Piedmont USA. X. Coastal productivity and persistence in response to fertilization and defoliation regimes. Agron. J. 96: 1400-1411.

Gunter, S. A., P. A. Beck, S. Hutchison, \& J. M. Phillips. 2005. Effects of stocking and nitrogen fertilization rates on steers grazing dallisgrass-dominated pasture. J. Anim. Sci. 83: 2235-2242.

Hirata, M., S. Ogura, K. Fukuyama, S. Kuroki, T. Inoue, T. Hidaka, T. Yuge, M. Takahashi, \& K. Nomura. 2003. Herbage production and utilization in a bahiagrass (Paspalum notatum Flugge) pasture grazed by breeding beef cows. Grassl. Sci. 48:477-484.

Holl, K. D. 2002. Long-term vegetation recovery on reclaimed coal surface mines in the eastern USA. J. Appl. Ecol. 39: 960-970.
Manske, L. L. 2004. A Method of Determining Stocking Rate Based on Monthly Standing Herbage Biomass. http:// www.ndsu.nodak.edu/dickinso/ [23 Pebruari 2010].

Mansyur, H. Djuned, T. Dhalika, \& L. Abdullah. 2006. Konsentrasi potasium, magnesium .dan ferum hijauan rumput Brachiaria humidicola (Rendle Schweick) pada metode penanaman dan berbagai interval pemotongan. Anim. Prod. 8: 34-43.

Mourinõ, F., F. K. Albrecht, D. M. Schaefer, \& P. Berzaghi. 2003. Steer performance on kura clover-grass and red clover-grass mixed pastures. Agron. J. 95: 652-659.

Nelson C. J. \& L. E. Moser. 1994. Plant Factors Affecting Forage Quality. In: Fahey GC (Ed). Forage Quality, Evaluation, and Utilization. American Society of Agronomy, Inc., Wisconsin.

Noble, J. C. 1994. Plant Population Ecology and Clonal Growth in Arid Rangeland Ecosystems. Rangelands: A Resource under Siege. Proceedings of Second International Rangeland Congress, Adelaide, 13 May 1994. Adelaide.

Sanderson M. A, K. J. Soder, N. Brzezinski, F. Taube, K. K1ement, L. D. Muller, \& M. Wachendorf. 2006. Sward structure of simple and complex mixtures of temperate forages. Agron. J. 98: 238-244.

Sanderson, M. A., S. C. Goslee, K. D. Klement, J. Kathy, \& K. J. Soder. 2007. Soil seed bank composition in pastures of diverse mixtures of temperate forages. Agron. J 99:15141520.

Shrestha, R. K. \& R. Lal. 2007. Soil carbon and nitrogen in 28year-old land uses in reclaimed coal mine soils of ohio. J. Environ. Qual. 36: 1775-1783.

Stuedemann, J. A. \& A. J. Franzluebbers. 2007. Cattle performance and production when grazing Bermudagrass at two forage mass levels in the southern Piedmont. J Anim Sci. 85: 1340-1350.

Suter, D., J. Nosberger, \& A. Luscher. 2001. Response of perennial ryegrass to free air CO2 enrichment (FACE) is related to the dynamics of sward structure during regrowth. Crop Sci. 41: 810-817.

Wadi, A., Y. Ishii, \& S. Idota. 2003. Effects of the level of fertilizer input on tiller and leaf development in relation with dry matter accumulation of napiergrass and kinggrass. Grassland Sci. 49:311-323.

Zackrisson, O., T. H. DeLuca, M.-C. Nilsson, A. Sellstedt, \& L. M. Berglund. 2004. Nitrogen fixation increases with successional age in boreal forests. Ecology 85: 3327-3334. 